\title{
RESEARCHES REGARDING THE INFLUENCE OF THE NUTRITION SPACE AT CASSIA ANGUSTIFOLIA Vahl. (SENNA) SPECIES CULTIVATED UNDER THE CONDITIONS OF A.R.D.S. SECUIENI
}

\author{
OANA MIRZAN ${ }^{* 1}$, MARGARETA NAIE ${ }^{1}$, SIMONA-FLORINA ISTICIOAIA ${ }^{1}$, \\ MARIA BOSTAN ${ }^{1}$, BOGDAN MIRZAN ${ }^{2}$ \\ ${ }^{1}$ Agricultural Research and Development Station Secuieni, Neamt County, 617415, \\ Romania \\ ${ }^{2}$ S.C. Agricola Moldoveni, Neamt County, Romania
}

\begin{abstract}
The present paper presents the results on the influence of the nutrition space at Cassia angustifolia Vahl. (Senna), cultivated under the conditions of A.R.D.S. Secuieni in 2017. The interaction of the studied factors was characterized by very significant negative differences to the production of fresh herb at Cassia angustifolia compared to the control variant $(30666 \mathrm{~kg} / \mathrm{ha})$ at the distance between rows of $50 \mathrm{~cm}$ and $70 \mathrm{~cm}$ at all three distances between plants per row (continuous row, $15 \mathrm{~cm}$ and $25 \mathrm{~cm}$ ).
\end{abstract}

Keywords: nutrition space, Senna, seeds

\section{INTRODUCTION}

Senna is widely used for its numerous benefits. Scientifically, it is known as Cassia angustifolia and belongs to family Fabaceae [1,2]. The plant is mainly valued for its cathartic properties and is mainly useful in habitual constipation. The laxative principles sennoside A and sennoside B, isolated from leaves and pods of senna, constitute important ingredients in purgative medicines [3]. The plant has been investigated for its various chemical constituents and pharmacological properties [3 - 7]

About 26 species of Cassia have been reported to contain anthracene derivatives either in their free form or as glycosides. The anthraquinone molecules are widely distributed in the genus Cassia and have remarkable biological properties in C. angustifolia and C. acutifolia [8, 9]. The researches were carried in 2017 at A.R.D.S. Secuieni and aimed establish the optimal nutritional space for the species Cassia angustifolia Vahl. in order to develop the technology cultivation.

\section{MATERIAL AND METHOD}

The researches were carried in 2017 at A.R.D.S. Secuieni on a typical cambic soil type. Characterized as being well supplied with mobile phosphorus ( $39 \mathrm{ppm}-\mathrm{P}_{2} \mathrm{O}_{5}$ ), moderately supplied in nitrogen with the soil nitrogen index of 2.1, well supplied in mobile potassium $\left(161 \mathrm{ppm}-\mathrm{K}_{2} \mathrm{O}\right)$, slightly acidic, with the $\mathrm{pH}$ (in aqueous suspension) of 6.29 and a humus content of $2.3 \%$. In order to development of technology cultivation at Cassia angustifolia Vahl. species one of the technological links studied was the optimal nutrition space.

\footnotetext{
* Corresponding author, email: spanuoana@yahoo.com

(c) 2018 Alma Mater Publishing House
} 
Experienced factors are: A - the distance between rows with graduations: $25 \mathrm{~cm}, 50 \mathrm{~cm}$ and $70 \mathrm{~cm}$ and B - the distance between plants per row with graduations: continuous row, $15 \mathrm{~cm}$ and $25 \mathrm{~cm}$.

The soil work and the preparation of the germination bed consisted in releasing the soil from the plant debris in the pre-planting, stubble-turning and plowing at a depth of $30 \mathrm{~cm}$. In spring, preparation of the germination bed was made with a harrow disc and the sowing was done manually at a $2 \mathrm{~cm}$ depth.

At Cassia angustifolia Vahl. species the observations and determinations during the vegetation period were the following: the number of branches/plant, the number of pods/plant, the seeds weight/plant, the production of fresh herb and seeds.

For the production of fresh herbs the plants were harvested manually until full blossom by cutting plants at a height of $5 \mathrm{~cm}$ from the ground. Seed harvesting was done by cutting plants with mowing, followed by barking. The seed obtained was conditioned by the small seed selector.

For the entire growing season of the Cassia angustifolia Vahl. species the deviation from the multiannual average of temperatures was $0.7^{\circ} \mathrm{C}$ (2017). In terms of rainfall recorded during the vegetation period at Cassia angustifolia Vahl., the year 2017 was less drought compared to the multiannual average (Table 1, Table 2).

Table 1. Temperatures recorded at A.R.D.S. Secuieni meteorological station.

\begin{tabular}{|c|c|c|c|c|c|c|c|c|c|c|c|c|}
\hline \multirow{2}{*}{$\begin{array}{c}\text { Average } \\
\text { temperature } \\
{ }^{\circ} \mathbf{C}\end{array}$} & \multicolumn{9}{|c|}{ Months } & \multirow{2}{*}{$\begin{array}{c}\text { Average } \\
\text { vegetation } \\
\text { period }\end{array}$} & \multirow{2}{*}{ Deviation } & \multirow{2}{*}{$\begin{array}{c}\text { Vegetation } \\
\text { period } \\
\text { characterization }\end{array}$} \\
\hline & Jan & Feb & Mar & Apr & May & Jun & Jul & Aug & Sept & & & \\
\hline 2017 & -5.7 & -1.8 & 7.0 & 9.1 & 15.4 & 20.3 & 20.4 & 21.2 & 16.3 & 17.1 & 0.7 & normal \\
\hline $\begin{array}{l}\text { Multiannual } \\
\text { average }\end{array}$ & -3.8 & -2.3 & 2.6 & 9.4 & 15.4 & 18.8 & 20.3 & 19.5 & 14.8 & 16.4 & - & - \\
\hline
\end{tabular}

Table 2. Rainfall recorded at A.R.D.S. Secuieni meteorological station.

\begin{tabular}{|c|c|c|c|c|c|c|c|c|c|c|c|c|}
\hline \multirow{2}{*}{$\begin{array}{l}\text { Rainfall } \\
\text { (mm) }\end{array}$} & \multicolumn{9}{|c|}{ Months } & \multirow{2}{*}{$\begin{array}{l}\text { Sum for the } \\
\text { vegetation } \\
\text { period }\end{array}$} & \multirow{2}{*}{ Deviation } & \multirow{2}{*}{$\begin{array}{l}\text { Negetation period } \\
\text { characterization }\end{array}$} \\
\hline & Jan & Feb & Mar & Apr & May & Jun & Jul & Aug & Sept & & & \\
\hline 2017 & 7.3 & 17.0 & 101.6 & 54.4 & 59.4 & 49.4 & 72.2 & 21.0 & 55.2 & 313.6 & -18.9 & less dry \\
\hline $\begin{array}{c}\text { Multiannual } \\
\text { average }\end{array}$ & 20.5 & 19.6 & 25.4 & 46.8 & 64.8 & 84.3 & 84.0 & 61.4 & 45.4 & 386.7 & - & - \\
\hline
\end{tabular}

\section{RESULTS AND DISCUSSION}

The average number of branches of the plant was between $2.06 \mathrm{~cm}$ and $5.2 \mathrm{~cm}$. The variant sown at the distance of $50 \mathrm{~cm}$ between the rows and $25 \mathrm{~cm}$ between the plants per row (a2xb3) and the variant sown at $70 \mathrm{~cm}$ between the rows and continuous (a3xb1), the difference from the control variant was positive significantly (5.2 and 5.13) compared to the control (a1xb1 - 2.07) (Table 3).

Interactions between a3xb1 (65.80 grams) and a3xb2 (61.53 grams) influenced the average number of pods per plant at Cassia angustifolia Vahl. compared to the control a1xb1 (35.47 grams), the differences being significant and distinctly significant (Table 4).

The low rainfall during the vegetation period affected the weight of the seeds/plant and implicitly the production of seeds per hectare. The obtained results on the interaction of the studied factors showed that the average weight of the seeds/plant recorded positive differences, distinctly significant the plants sown at $70 \mathrm{~cm}$ between the rows at all three distances between plants per row (continuous row, $15 \mathrm{~cm}$ and $25 \mathrm{~cm}$ ), namely a3xb1 (30.16 grams), a3xb2 (30.18 grams) and a3xb3 (26.59 grams) compared to control variant a1 xb1 (sown at $25 \mathrm{~cm}$ between rows and plant spacing per row continuously -15.49 grams) (Table 5).

High temperatures and rainfall during the vegetation period have influenced the yield of fresh herb / hectare. The interaction of the studied factors was characterized by very significant negative differences in the production of fresh herb at Cassia angustifoliaVahl. compared to the control variant $(30666 \mathrm{~kg} / \mathrm{ha})$ at the distance between rows of $50 \mathrm{~cm}$ and $70 \mathrm{~cm}$ at all three distances between plants per row (continuous row, $15 \mathrm{~cm}$ and $25 \mathrm{~cm}$ ) (Table 6). 
Table 3. Influence of the interaction between row spacing and plant spacing in relation to the average number of branches per plant in Cassia angustifolia Vahl. (Senna) species at A.R.D.S. Secuieni in 2017.

\begin{tabular}{|l|c|c|c|c|c|}
\hline $\begin{array}{c}\text { Distance between } \\
\text { rows (A) }\end{array}$ & $\begin{array}{c}\text { Distance between } \\
\text { plants per row (B) }\end{array}$ & $\begin{array}{c}\text { Number of } \\
\text { branches } \\
\text { /plant }\end{array}$ & $\begin{array}{c}\text { \% } \\
\text { compared } \\
\text { to control }\end{array}$ & Diff. & Significance \\
\hline \multirow{3}{*}{ a1-25 cm } & b1- continuous row & 2.07 & 100 & Ct. & \\
\cline { 2 - 6 } & b2-15 cm & 2.06 & 99.51 & -0.01 & \\
\cline { 2 - 6 } & b3-25 cm & 3.60 & 174.19 & 1.53 & \\
\hline \multirow{3}{*}{ a2-50 cm } & b1- continuous row & 3.13 & 151.20 & 1.06 & \\
\cline { 2 - 6 } & b2-15 cm & 2.47 & 119.32 & 0.4 & $*$ \\
\hline \multirow{3}{*}{ a3-70 cm } & b3-25 cm & 5.20 & 251.20 & 3.13 & $*$ \\
\hline & b1- continuous row & 5.13 & 247.82 & 3.06 & $*$ \\
\cline { 2 - 7 } & b2-15 cm & 4.60 & 222.22 & 2.53 & \\
\cline { 2 - 7 } & b3-25 cm & 2,87 & 138.64 & 0.8 & \\
\hline
\end{tabular}

Positive significantly, *.

Table 4. Influence of the interaction between row spacing and plant spacing in relation to the average number of pods per plant in Cassia angustifolia Vahl. (Senna) species at A.R.D.S. Secuieni in 2017.

\begin{tabular}{|c|c|c|c|c|c|}
\hline \multirow{2}{*}{$\begin{array}{c}\text { Distance between } \\
\text { rows (A) }\end{array}$} & $\begin{array}{c}\text { Distance between } \\
\text { plants per row (B) }\end{array}$ & $\begin{array}{c}\text { Number of } \\
\text { pods/plant } \\
(\mathbf{g})\end{array}$ & $\begin{array}{c}\text { \% } \\
\text { compared } \\
\text { to control }\end{array}$ & Diff. & Significance \\
\hline \multirow{3}{*}{ a1-25 cm } & b1- continuous row & 35.47 & 100 & Ct. & \\
\cline { 2 - 6 } & b2-15 cm & 34.73 & 97.93 & -0.73 & \\
\cline { 2 - 7 } & b3-25 cm & 32.53 & 91.72 & -2.93 & \\
\hline \multirow{3}{*}{ a2-50 cm } & b1- continuous row & 41.00 & 115.59 & 5.53 & \\
\cline { 2 - 7 } & b2-15 cm & 40.40 & 113.89 & 4.93 & \\
\cline { 2 - 7 } & b3-25 cm & 42.60 & 120.10 & 7.13 & \\
\hline \multirow{3}{*}{ a3-70 cm } & b1- continuous row & 65.80 & 185.50 & 30.33 & $*$ \\
\cline { 2 - 7 } & b2-15 cm & 61.53 & 173.47 & 26.06 & \\
\cline { 2 - 7 } & b3-25 cm & 53.47 & 150.74 & 18.00 & \\
\hline
\end{tabular}

Positive significantly, *; Positive distinct significantly, **

Analyzing the interaction between distance spacing and the distance between plants per row on average seed production, it was found to vary between $1249 \mathrm{~kg} / \mathrm{ha}$ at a2xb1 (line spacing of $50 \mathrm{~cm}$ continuously sown) and $2774 \mathrm{~kg} / \mathrm{ha}$ at a1xb3 the distance between rows $25 \mathrm{~cm}$ and the distance between plants per row of $25 \mathrm{~cm}$ (Table 7).

Table 5. Influence of the interaction between row spacing and plant spacing in relation to the average seed weight per plant in Cassia angustifolia Vahl. (Senna) species at A.R.D.S. Secuieni in 2017.

\begin{tabular}{|c|c|c|c|c|c|}
\hline $\begin{array}{l}\text { Distance between } \\
\text { rows }(\mathrm{A})\end{array}$ & $\begin{array}{c}\text { Distance between plants } \\
\text { per row }(\mathrm{B})\end{array}$ & $\begin{array}{c}\text { Seed } \\
\text { weight/plant } \\
\text { (g) }\end{array}$ & $\begin{array}{c}\% \\
\text { compared } \\
\text { to control }\end{array}$ & Diff. & Significance \\
\hline \multirow{3}{*}{ a1-25 cm } & b1- continuous row & 15.49 & 100 & Ct. & \\
\hline & $\mathrm{b} 2-15 \mathrm{~cm}$ & 18.14 & 117.15 & 2.66 & \\
\hline & $\mathrm{b} 3-25 \mathrm{~cm}$ & 14.05 & 90.70 & -1.44 & \\
\hline \multirow{3}{*}{$\mathrm{a} 2-50 \mathrm{~cm}$} & b1- continuous row & 17.14 & 110.65 & 1.65 & \\
\hline & $\mathrm{b} 2-15 \mathrm{~cm}$ & 17.88 & 115.42 & 2.39 & \\
\hline & $\mathrm{b} 3-25 \mathrm{~cm}$ & 19.43 & 125.43 & 3.94 & \\
\hline \multirow{3}{*}{$\mathrm{a} 3-70 \mathrm{~cm}$} & b1- continuous row & 30.16 & 194.70 & 14.67 & $* *$ \\
\hline & $\mathrm{b} 2-15 \mathrm{~cm}$ & 30.18 & 194.83 & 14.69 & $* *$ \\
\hline & b3-25 cm & 26.59 & 171.65 & 11.1 & $* *$ \\
\hline
\end{tabular}

Positive distinct significantly, **. 
Table 6. Influence of the interaction between row spacing and plant spacing in relation to the average fresh herbs (kg/ha) in Cassia angustifolia Vahl. (Senna) species at A.R.D.S. Secuieni in 2017.

\begin{tabular}{|c|c|c|c|c|c|}
\hline $\begin{array}{l}\text { Distance between } \\
\text { rows (A) }\end{array}$ & $\begin{array}{c}\text { Distance between plants } \\
\text { per row (B) }\end{array}$ & $\begin{array}{c}\text { Production } \\
\text { of fresh } \\
\text { herb (kg/ha) }\end{array}$ & $\begin{array}{c}\% \\
\text { compared } \\
\text { to control }\end{array}$ & Diff. & Significance \\
\hline \multirow{3}{*}{ a1-25 cm } & b1- continuous row & 30666 & 100 & Ct. & \\
\hline & $\mathrm{b} 2-15 \mathrm{~cm}$ & 23013 & 75.04 & -7653 & $\mathrm{o}$ \\
\hline & $\mathrm{b} 3-25 \mathrm{~cm}$ & 22586 & 73.65 & -8000 & o \\
\hline \multirow{3}{*}{$\mathrm{a} 2-50 \mathrm{~cm}$} & b1- continuous row & 15633 & 50.97 & -15033 & 000 \\
\hline & $\mathrm{b} 2-15 \mathrm{~cm}$ & 15280 & 49.82 & -15386 & ooo \\
\hline & $\mathrm{b} 3-25 \mathrm{~cm}$ & 13406 & 43.71 & -17260 & 000 \\
\hline \multirow{3}{*}{$\mathrm{a} 3-70 \mathrm{~cm}$} & b1- continuous row & 16773 & 54.69 & -13893 & 000 \\
\hline & $\mathrm{b} 2-15 \mathrm{~cm}$ & 14286 & 46.58 & -16380 & 000 \\
\hline & $\mathrm{b} 3-25 \mathrm{~cm}$ & 14486 & 47.23 & -16180 & 000 \\
\hline
\end{tabular}

Negative significantly, o; Negative very significant, ooo.

Table 7. Influence of the interaction between row spacing and plant spacing in relation to the average seed production (kg/ha) in Cassia angustifolia Vahl. (Senna) species at A.R.D.S. Secuieni in 2017.

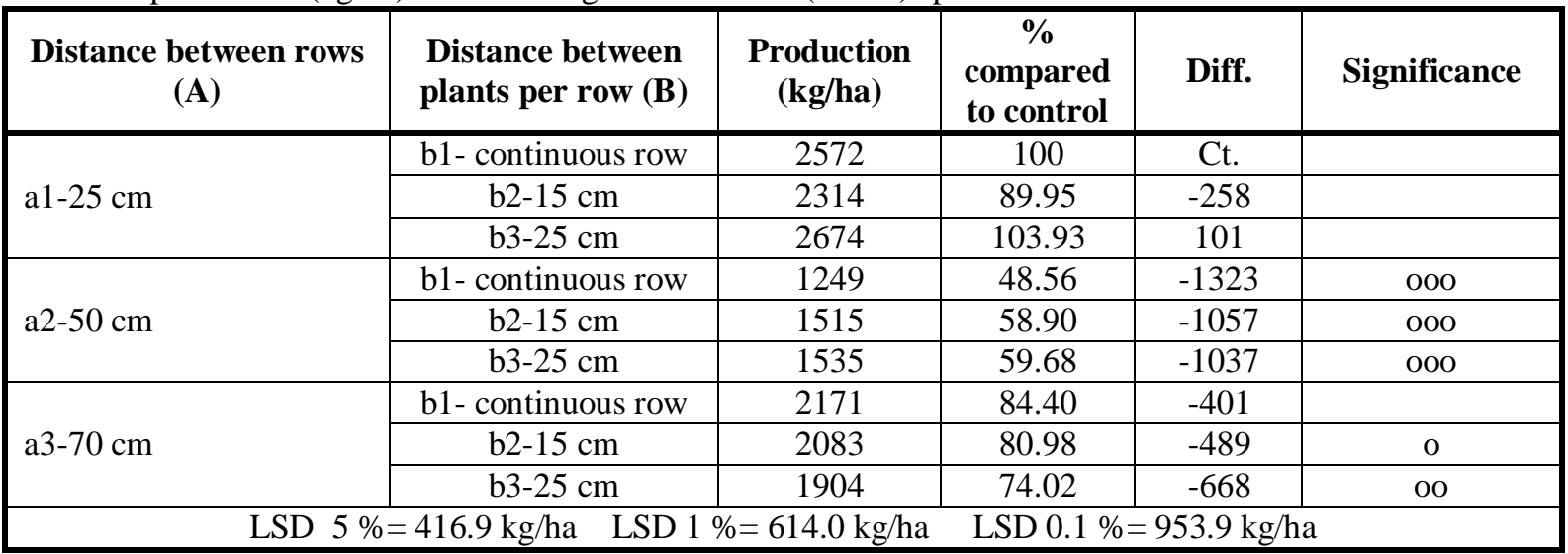

Negative significantly, o; Negative distinct significantly, oo; Negative very significant, ooo.

\section{CONCLUSIONS}

Under the conditions of A.R.D.S. Secuieni, due to high temperatures and low rainfall during certain months of the vegetation period at the distances of $50 \mathrm{~cm}$ and $70 \mathrm{~cm}$ between the rows there was a decrease of the herb and seed production as compared to the control of the experience sowing at $25 \mathrm{~cm}$ between the rows and continuously row during the 2017.

The interaction of the studied factors was characterized by very significant negative differences at the yield of fresh herb compared to the control variant $(30666 \mathrm{~kg} / \mathrm{ha}$ ) at the distance between rows of $50 \mathrm{~cm}$ and $70 \mathrm{~cm}$ at all three distances between plants per row .

Large deficits yield were obtained at the $50 \mathrm{~cm}$ between the rows at all three distances between plants per row. The low rainfall in certain months of vegetation periods has influenced seed production at Senna species.

Being a new species introduced into culture, it requires all the attention the growers of medicinal plants.

\section{REFERENCES}

[1] Khan, M.A., Ahmad, M., Zafar, M., Sultana, S., Shaheen S., Leghari, M.K., Jan, G., Ahmad, F., Nazir, A., Medico-botanical and chemical standardization of pharmaceutically important plant of Tricholepis chaetolepis (Boiss.), Journal of Medicinal Plants Research, vol. 8, no. 5, 2011, p. 1471-1477. 
[2] Shazia, S., Mushtaq, A., Muhammad, Z., Mir Ajab, K. Muhammad, A., Authentication of herbal drug Senna (Cassia angustifolia Vahl.): A village pharmacy for Indo-Pak Subcontinent, African Journal of Pharmacy and Pharmacology, vol. 6, no. 30, 2012, p. 2299-2308.

[3] Tripathi, Y.C., Cassia angustifolia, a versatile medicinal crop, International Tree Crops Journal, vol. 10, 1999.

[4] Buburuz, A.A., Popa, L.D., The productivity of some monoecious hemp varieties (for fiber and mixte) under the center of Moldavia ecopedoclimatic conditions, Journal of Engineering Studies and Research, vol. 23, no. 2, 2017, p. 7- 11.

[5] Naie, M., Mirzan, O., Dobrea, D.I., Researches regarding the influence of the nutrition space at Dracocephalum Moldavica 1. (Dragonhead) species cultivated under the conditions of A.R.D.S. Secuieni, Journal of Engineering Studies and Research, vol. 23, no. 2, 2017, p. 16-21.

[6] Ursache, P.L., Trotus, E., Buburuz, A.A., Observations concerning the harmful Entomofauna from winter rapeseed crops in the conditions of Central of Moldava, between years 2014-2017, Journal of Engineering Studies and Research, vol. 23, no. 2, 2017, p. 33-41.

[7] Irimia, O., Nedeff, V., Panainte Lehadus, M., Tomozei, C., Experimental study concerning the distribution of granular particle shape from a filter layer, Journal of Engineering Studies and Research, vol. 22, no. 1, 2016 , p. 64-71.

[8] Ganapaty, S., Thomas, P.S., Ramana, K.V., Vidyadhar, K., Chakradhar, V., A review of phytochemical studies of Cassia species, Journal of Natural Remedies, vol. 2, 2002, p. 102 - 120.

[9] Ram, P., Mehrotra, B.N., Compendium of Indian medicinal Plants, CDRI Publications: Lucknow, 1999, p. 147-156. 